\title{
Correlation of High Pressure Density Behaviors for Fluid Mixtures made of Carbon Dioxide with Solvent at 313.15 K
}

\author{
Masahiro Kato ${ }^{1, *}$, Masaki Kokubo, Kensuke Ohashi, Atsushi Sato and Daisuke Kodama ${ }^{2, *}$ \\ Department of Materials Chemistry and Engineering, College of Engineering, Nihon University, Koriyama, Fukushima \\ 963-8642, Japan
}

\begin{abstract}
High pressure density behaviors for fluid mixtures made of carbon dioxide with solvent, methyl acetate, ethyl acetate, 2-propyl acetate, methanol, 1-propanol, or 2-propanol, at $313.15 \mathrm{~K}$ were satisfactorily correlated. The standard deviations were between 0.4 and $2.2 \mathrm{~kg} \mathrm{~m}^{-3}$ in density for each system in the composition range from 0.00 to 0.95 mole fraction of carbon dioxide.
\end{abstract}

\section{INTRODUCTION}

Carbon dioxide is the most popular component as a supercritical fluid. The fluid behaviors of mixtures made of supercritical carbon dioxide with solvent are required in the design and operation of supercritical extraction processes. Methyl acetate, ethyl acetate, 2-propyl acetate, methanol, 1propanol, and 2-propanol are typical worthy solvents in chemical industry. The authors [1-6] therefore measured the high pressure density behaviors for fluid mixtures made of supercritical carbon dioxide with those solvents. In the previous studies, an equation for the correlation of density behaviors of fluid mixtures at high pressures was presented. The composition range was limited from 0.00 to 0.80 mole fraction of carbon dioxide. In the present study, an equation for the correlation of density behaviors of fluid mixtures at high pressures is presented to expand the applicable composition range from 0.00 till 0.95 mole fraction of carbon dioxide, modifying the previous equation. With the present density equation, the high pressure density data previously reported by the authors for six binary mixtures made of supercritical carbon dioxide with solvent, methyl acetate, ethyl acetate, 2-propyl acetate, methanol, 1-propanol, or 2propanol, at $313.15 \mathrm{~K}$ were successfully correlated.

\section{DENSITY DATA}

The experimental density data at high pressures were obtained with the variable volume apparatus equipped with the vibrating tube densimeters. The apparatus was described previously [1-6]. The maximum operating temperature and pressure of the apparatus are $400 \mathrm{~K}$ and $20 \mathrm{MPa}$, respectively. The main parts of the apparatus are a variable volume cell, piston, Ruska 2465-752 and Ruska 2470-703 air lubricated dead weight gauge, Ruska 2480-700 oil dead weight gauge, hand pump syringe, Anton Paar DMA 512P vibrating tube densimeters, circulation pumps, gas reservoir, and Ruska 2439-702 pressure transducers. The vibrating tube

*Address correspondence to this author at the Department of Materials Chemistry and Engineering, College of Engineering, Nihon University, Koriyama, Fukushima 963-8642, Japan; Tel: +81-24-956-8816/Tel: +81-24956-8813; Fax: +81-24-956-8862/Fax: +81-24-956-8862;

E-mails: mkatoh@chem.ce.nihon-u.ac.jp/dkodama@chem.ce.nihon-u.ac.jp densimeters were calibrated by dry air and pure water at the experimental temperature.

The apparatus is housed in a constant temperature liquid bath controlled to a temperature to about $\pm 0.01 \mathrm{~K}$. Temperatures were measured with the Hewlett Packard 2804A quartz thermometer calibrated by the triple point of water. The volume of the lower portion of the cell could be varied between 234 and $299 \mathrm{~cm}^{3}$ by moving a piston, which gave a volume uncertainty of $\pm 0.01 \mathrm{~cm}^{3}$. First, the cell is evacuated and then filled with carbon dioxide. The pressure difference between the upper and lower spaces is kept close to null, to minimize the leakage between the upper and lower rooms in the cell. The volume is determined by the motion of the piston. The amount of carbon dioxide is determined from the volume and density.

The solvent was first degassed by the ultrasonic generator in vacuum about 15 minutes. The solvent is then charged into the cell with the syringe pump with an uncertainty \pm 0.01 $\mathrm{cm}^{3}$. After pressurizing the syringe pump, the solvent is injected into the cell as quickly as possible, to eliminate the dissolution effect of carbon dioxide into the solvent in the syringe pump. The amount of solvent can be determined by the volume and density. The composition of the mixture was evaluated by the amount of carbon dioxide and the one of the solvent injected into the cell. As the volume of cell is changed, the volumetric properties of the mixture can be measured at a fixed and known composition The reliability of the experimental procedures had been confirmed by the agreement between the synthetic bubble point pressure measurements with the present apparatus and the analytical vapor-liquid equilibrium measurements in the separate conventional apparatus $[4,7]$. The high pressure density behaviors for fluid mixtures made of carbon dioxide with methyl acetate, ethyl acetate, 2-propyl acetate, methanol, 1propanol, or 2-propanol at $313.15 \mathrm{~K}$ were measured by the authors [1-6]. For carbon dioxide+ethyl acetate, the density data reported by Smith et al. [8] deviated $0.8 \mathrm{~kg} \mathrm{~m}^{-3}$ from the experimental ones reported by the authors [2].

The experimental uncertainties of the pressure, density, temperature and composition are $0.001 \mathrm{MPa}, 0.1 \mathrm{~kg} \mathrm{~m}^{-3}$, $0.01 \mathrm{~K}$, and 0.001 mole fraction, respectively. Carbon diox- 
ide is given with the guarantee better than $99.9 \mathrm{~mol} \%$. The purities of solvents, methyl acetate, ethyl acetate, 2-propyl acetate, methanol, 1-propanol, and 2-propanol, are 99.9, 99.9, 99.9, 99.8, 99.9, and $99.9 \mathrm{~mol} \%$ in gas chromatograph peak areas, respectively.

\section{DENSITY EQUATION}

The high pressure density data [1-6] of the six fluid mixtures made of carbon dioxide with methyl acetate, ethyl acetate, 2-propyl acetate, methanol, 1-propanol, or 2-propanol at $313.15 \mathrm{~K}$ have been correlated by the following density Eq. (1).

$$
\rho=\frac{x_{1} \rho_{1}^{0^{*}}+x_{2} \rho_{2}^{0^{*}}+\alpha x_{1} x_{2}\left\{\frac{x_{1}+\beta x_{2}}{x_{1}-\kappa x_{1} x_{2}+\lambda x_{2}}\right\}}{1-\ln \left\{1-\frac{1-\left(P / P^{*}\right)}{1+\exp \left[A-B /\left(x_{1}+6 x_{2}\right)\right]}\right\}}
$$

where, $\rho, x$, and $P$ are density, composition of mole fraction, and pressure, respectively. The superscript 0 denotes pure. $P^{*}$ means the reference pressure at high pressure. The subscripts, 1 and 2, denote carbon dioxide and solvent, respectively. Eq. (1) has six parameters, $\alpha, \beta, \kappa, \lambda, A$, and $B$. Those parameters are independent on composition.

Smith et al. [8] correlated their volumetric density data for supercritical carbon dioxide+ester mixtures with the Tait equation $[8,9]$ for liquid density at high pressure. The authors [2] previously correlated the density data for carbon dioxide-ethyl acetate by the nine parameter density equation, modified the Tait equation [8,9]. The parameters were evaluated by giving selected individual points, not with the optimization. In the next study [10], the previous density equation was simplified to reduce the number of parameters from nine to eight. The eight parameters are obtained by the optimization of the Marquardt method to minimize the sum of the square of the difference between the calculated density and experimental one in the composition range of the mole fraction of carbon dioxide from 0.00 to 0.80 .

In the present study, the previous density equation was simplified to reduce the number of parameters from eight to six. The applicable composition range was expanded from 0.00 to 0.95 in the mole fraction of carbon dioxide. The previous applicable composition range was from 0.00 to 0.80 . The parameters in Eq. (1) and the average standard deviations are shown in Table 1, giving fine results as the standard deviations between 0.4 and $2.2 \mathrm{~kg} \mathrm{~m}^{-3}$ in density. The average standard deviations are 1.1 and 3.3, respectively, in the present study and the previous study [10] for the composition range from 0.00 to 0.95 of mole fraction of carbon dioxde. The average standard deviation of density in the composition range over 0.80 till 0.95 are 3.1 and $12.7 \mathrm{~kg} \mathrm{~m}^{-3}$, respectively, in the present study and the previous study [10].

Fig. (1) gives the density behaviors of carbon dioxide+ethyl acetate system at $313.15 \mathrm{~K}$, with high performance of Eq. (1) for the density calculation. The points denote the experimental data given by the authors [2] and by Smith et al. [8] in Fig. (1). The continuing line and dotted one, respectively, show the calculation results by Eq. (1) in the pre-

Table 1. Parameters in Density Equation for Fluid Mixtures at 313.15 K

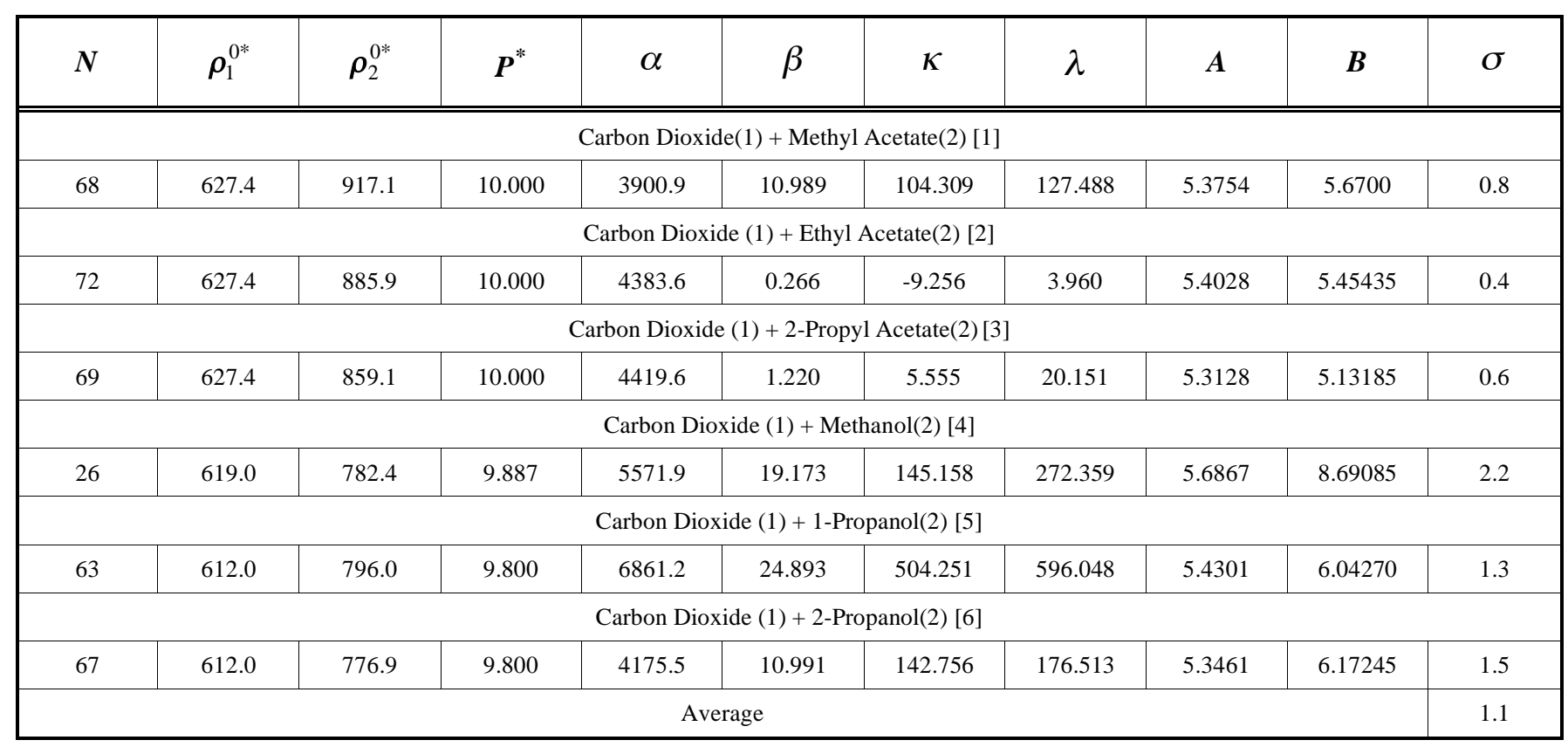

$\sigma$ :standard deviation $\quad \sigma=\sqrt{\frac{\sum\left(\rho_{\text {calc }}-\rho_{\text {expl }}\right)^{2}}{\mathrm{~N}-1}}\left(\mathrm{~kg} \mathrm{~m}^{-3}\right)$

$N$ : number of data points, $\rho_{1}^{0^{*}}:$ density of $\mathrm{CO}_{2}$ at reference pressure $\left(\mathrm{kg} \mathrm{m}^{-3}\right)$

$\rho_{2}^{0^{*}}$ : density of solvent at reference pressure $\left(\mathrm{kg} \mathrm{m}^{-3}\right), P^{*}$ : reference pressure $(\mathrm{MPa})$ 
sent study and the calculated ones in the previous study [10]. The molar volume was calculated by the following Eqs. (2) and (3).

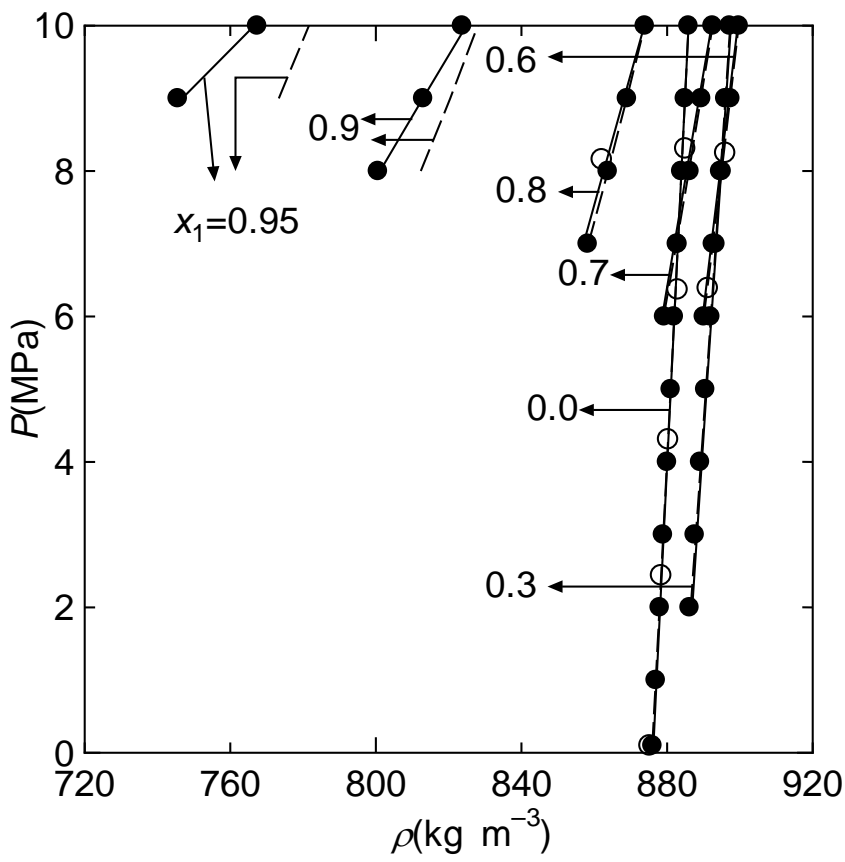

Fig. (1). Volumetric property for carbon dioxide(1) + ethyl acetate(2) at $313.15 \mathrm{~K}$.

Experimental

: Kato et al. [2],

O: Smith et al. [8]

Calculated

Eq. (1), - . - . - - Kato et al. [10].

$$
\begin{aligned}
& V=\frac{M}{\rho} \\
& M=x_{1} M_{1}+x_{2} M_{2}
\end{aligned}
$$

where, $V, M, x$, and $\rho$ denote the molar volume, molecular weight, composition in mole fraction, and density, respectively. The subscripts, 1 and 2, denote carbon dioxide and solvent, respectively.

Fig. (2) shows the molar volume at the reference high pressures for six fluid mixtures made of carbon dioxide with methyl acetate, ethyl acetate, 2-propyl acetate, methanol, 1propanol, or 2-propanol at $313.15 \mathrm{~K}$.

The partial molar volumes of carbon dioxide and solvent were calculated as follows:

$$
\begin{aligned}
& \overline{V_{1}}=V+x_{2}\left(\frac{d V}{d x_{1}}\right) \\
& \overline{V_{2}}=V-x_{1}\left(\frac{d V}{d x_{1}}\right)
\end{aligned}
$$

in which, $\bar{V}$ and $x$, respectively, denote the partial molar volume and composition in mole fraction. The subscripts, 1 and 2 , denote carbon dioxide and solvent, respectively.

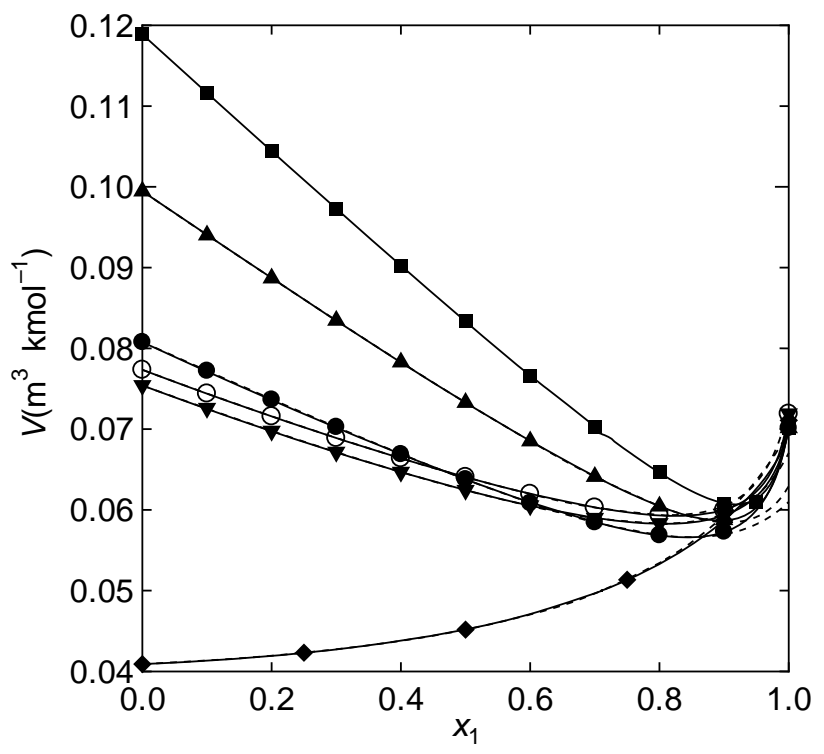

Fig. (2). Molar volumes of fluid mixtures at $313.15 \mathrm{~K}$. Experimental

: $\mathrm{CO}_{2}(1)+$ methyl acetate(2) at $313.15 \mathrm{~K}$ and $10.000 \mathrm{MPa}$

$\mathbf{\Delta}: \mathrm{CO}_{2}(1)+$ ethyl acetate(2) at $313.15 \mathrm{~K}$ and $10.000 \mathrm{MPa}$

: $\mathrm{CO}_{2}(1)+2$-propyl acetate(2) at $313.15 \mathrm{~K}$ and $10.000 \mathrm{MPa}$

$\checkmark$ : $\mathrm{CO}_{2}(1)+$ methanol(2) at $313.15 \mathrm{~K}$ and $9.887 \mathrm{MPa}$

$\nabla: \mathrm{CO}_{2}(1)+1-p r o p a n o l(2)$ at $313.15 \mathrm{~K}$ and $9.800 \mathrm{MPa}$

$\mathrm{O}: \mathrm{CO}_{2}(1)+2$-propanol(2) at $313.15 \mathrm{~K}$ and $9.800 \mathrm{MPa}$

Calculated

Eq. (1) , - - . - . - Kato et al. [10].

Figs. (3) and (4) show the partial molar volume of carbon dioxide and each solvent at the reference pressure $P^{*}$, respectively. As shown in Fig. (3), the partial molar volume of carbon dioxide grew large, increasing the composition of carbon dioxide. As shown in Fig. (4), the partial molar volume of solvent sharply fell in the high composition range of carbon dioxide.

The partial molar volume of carbon dioxide at infinite dilution $\bar{V}_{1}^{\infty}$ was calculated as follows:

$$
{\overline{V_{1}}}^{\infty}=V_{2}^{0}+\left(\frac{d V}{d x_{1}}\right)_{x_{1}=0}
$$

where $V_{2}^{0}$ represents the molar volume of pure solvent at given pressure.

Fig. (5) shows the partial molar volume of carbon dioxide at infinite dilution, giving the linear relation with pressure.

\section{CONCLUSIONS}

An equation for the correlation of high pressure density behaviors of fluid mixtures made of carbon dioxide with methyl acetate, ethyl acetate, 2-propyl acetate, methanol, 1propanol, or 2-propanol at $313.15 \mathrm{~K}$ was presented with the standard deviations between 0.4 and $2.2 \mathrm{~kg} \mathrm{~m}^{-3}$ in density in the composition range from 0.00 to 0.95 mole fraction of carbon dioxide. 


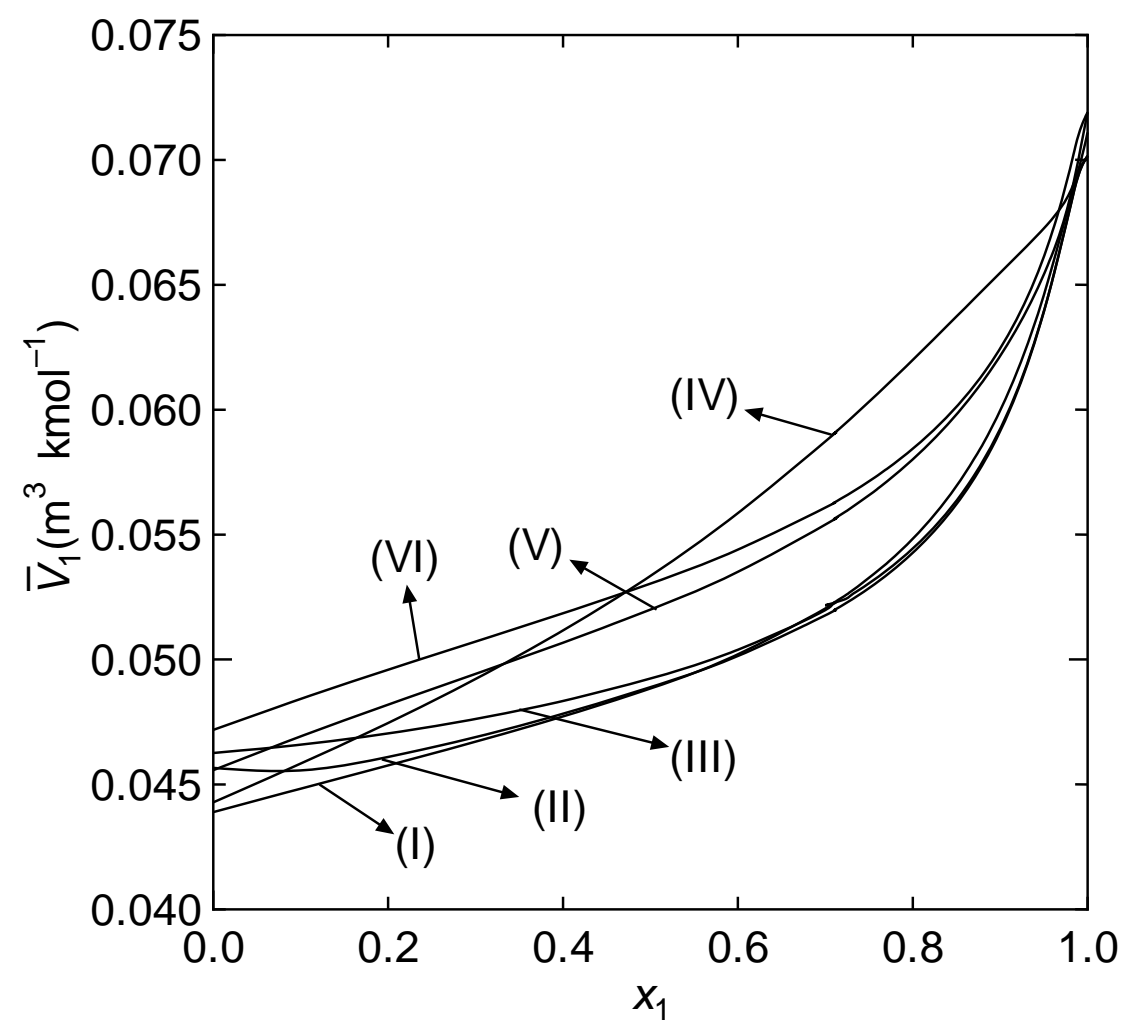

Fig. (3). Partial molar volume of carbon dioxide in fluid mixtures at high pressures $P^{*}$.

(I) $\mathrm{CO}_{2}(1)+$ methyl acetate(2) at $313.15 \mathrm{~K}$ and $10.000 \mathrm{MPa}$

(III) $\mathrm{CO}_{2}(1)+2$-propyl acetate(2) at $313.15 \mathrm{~K}$ and $10.000 \mathrm{MPa}$

(V) $\mathrm{CO}_{2}(1)+1-\operatorname{propanol}(2)$ at $313.15 \mathrm{~K}$ and $9.800 \mathrm{MPa}$
(II) $\mathrm{CO}_{2}(1)+$ ethyl acetate(2) at $313.15 \mathrm{~K}$ and $10.000 \mathrm{MPa}$

(IV) $\mathrm{CO}_{2}(1)+$ methanol(2) at $313.15 \mathrm{~K}$ and $9.887 \mathrm{MPa}$

(VI) $\mathrm{CO}_{2}(1)+2-\operatorname{propanol}(2)$ at $313.15 \mathrm{~K}$ and $9.800 \mathrm{MPa}$

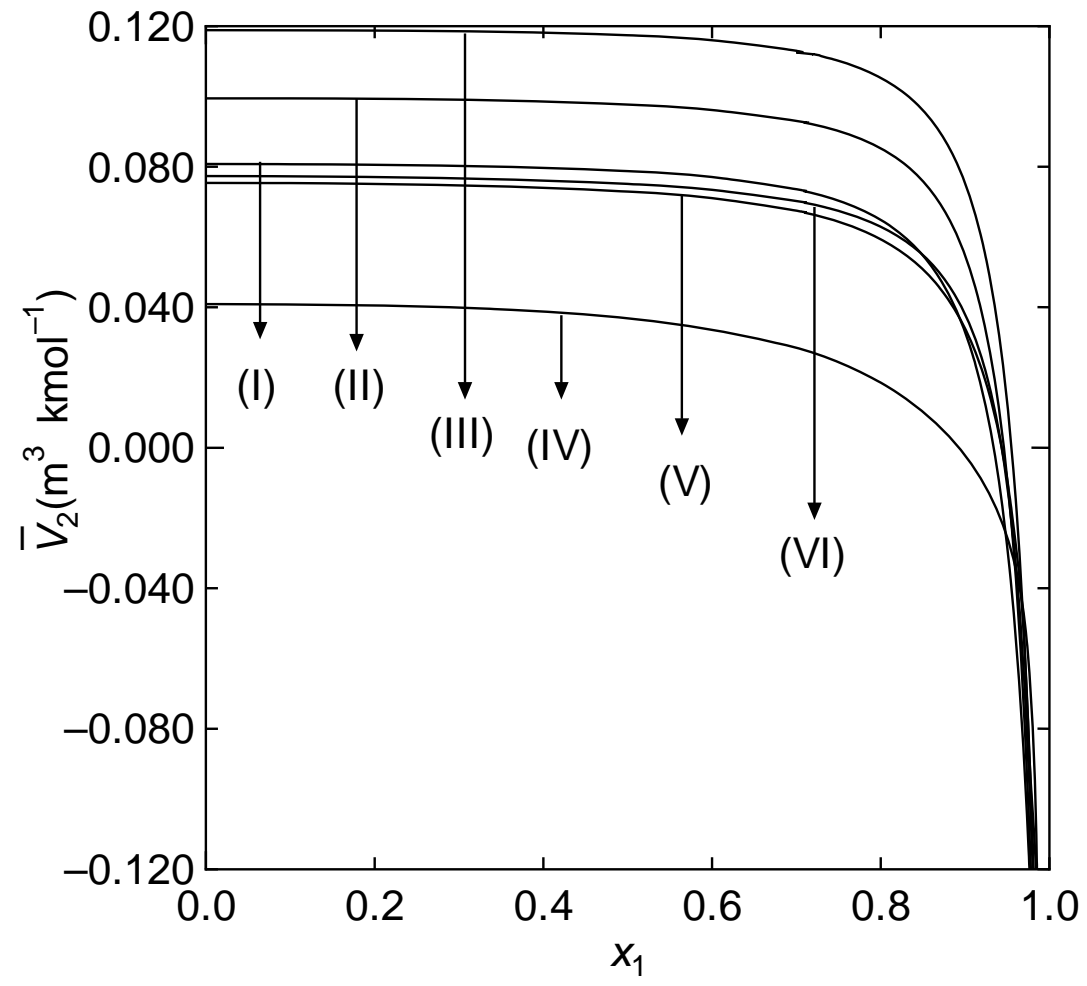

Fig. (4). Partial molar volume of solvents in fluid mixtures at high pressure $P^{*}$.

(I) $\mathrm{CO}_{2}(1)+$ methyl acetate(2) at $313.15 \mathrm{~K}$ and $10.000 \mathrm{MPa}$

(III) $\mathrm{CO}_{2}(1)+2$-propyl acetate(2) at $313.15 \mathrm{~K}$ and $10.000 \mathrm{MPa}$

(V) $\mathrm{CO}_{2}(1)+1$-propanol(2) at $313.15 \mathrm{~K}$ and $9.800 \mathrm{MPa}$
(II) $\mathrm{CO}_{2}(1)+$ ethyl acetate(2) at $313.15 \mathrm{~K}$ and $10.000 \mathrm{MPa}$

(IV) $\mathrm{CO}_{2}(1)+$ methanol(2) at $313.15 \mathrm{~K}$ and $9.887 \mathrm{MPa}$

(VI) $\mathrm{CO}_{2}(1)+2$-propanol(2) at $313.15 \mathrm{~K}$ and $9.800 \mathrm{MPa}$ 


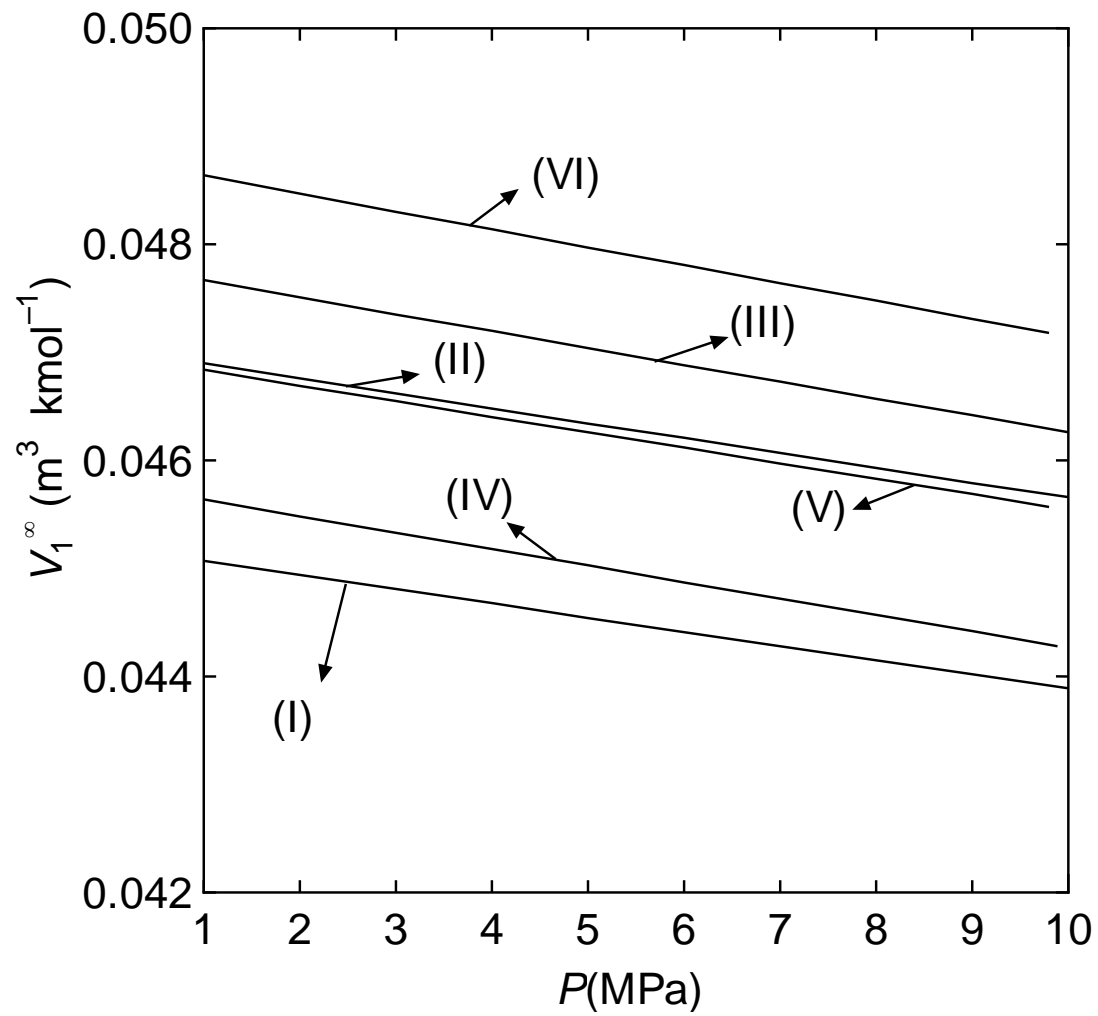

Fig. (5). Partial molar volume of carbon dioxide at infinite dilution in fluid mixtures.
(I) $\quad \mathrm{CO}_{2}(1)+$ methyl acetate(2) at $313.15 \mathrm{~K}$
(III) $\mathrm{CO}_{2}(1)+2$-propyl acetate(2) at $313.15 \mathrm{~K}$
(V) $\mathrm{CO}_{2}(1)+1-\operatorname{propanol}(2)$ at $313.15 \mathrm{~K}$

\section{NOMENCLATURE}

$\begin{array}{lll}\mathrm{A}, \mathrm{B}, \alpha, \beta, \kappa, \lambda & = & \text { Parameters in Eq. (1) } \\ \mathrm{M} & = & \text { Molecular weight }\left(\mathrm{kg} \mathrm{kmol}^{-1}\right) \\ \mathrm{N} & = & \text { Number of data points } \\ \mathrm{P} & = & \text { Pressure }(\mathrm{MPa}) \\ \mathrm{V} & = & \text { Molar volume }\left(\mathrm{m}^{3} \mathrm{kmol}^{-1}\right) \\ \mathrm{V} & = & \text { Partial molar volume }\left(\mathrm{m}^{3} \mathrm{kmol}^{-1}\right) \\ \mathrm{X} & = & \text { Mole fraction } \\ \mathrm{p} & = & \text { Density }\left(\mathrm{kg} \mathrm{m}{ }^{-3}\right) \\ \sigma \text { Subscripts } & = & \text { Standard deviation on density } \\ 1 & & \left.\text { (kg m }{ }^{-3}\right) \\ 2 & = & \text { Carbon dioxide } \\ \text { calc } & =\text { Colvent } \\ \text { expl superscripts } & =\text { Experimental } \\ 0 & =\text { Pure } \\ * & =\text { Reference state } \\ \infty & \text { Infinite dilution } \\ & & \end{array}$

\section{ACKNOWLEDGEMENT}

The authors thank Mr. Takeshi Ono for his help in the present study.
(II) $\mathrm{CO}_{2}(1)+$ ethyl acetate(2) at $313.15 \mathrm{~K}$

(IV) $\mathrm{CO}_{2}(1)+$ methanol(2) at $313.15 \mathrm{~K}$

(VI) $\mathrm{CO}_{2}(1)+2-\operatorname{propanol}(2)$ at $313.15 \mathrm{~K}$

\section{REFERENCES}

[1] M. Kato, K. Sugiyama, M. Sato, and D. Kodama, "Volumetric property for carbon dioxide + methyl acetate system at $313.15 \mathrm{~K}$ ", Fluid Phase Equilibria, vol. 257, pp. 207-211, August 2007.

[2] M. Kato, D. Kodama, M. Sato, and K. Sugiyama, "Volumetric behavior and saturated pressure for carbon dioxide + ethyl acetate at a temperature of 313.15K", J. Chem. Eng. Data, vol. 51, pp. 1031-1034, February 2006.

[3] D. Kodama, K. Sugiyama, T. Ono, and M. Kato, "Volumetric properties of carbon dioxide + isopropyl ethanoate mixtures at 308.15 and 313.15K", J. Supercrit. Fluids, vol. 47, pp. 128-134, December 2008.

[4] D. Kodama, N. Kubota, Y. Yamaki, H. Tanaka, and M. Kato, "High pressure vapor-liquid equilibria and density behaviors for carbon dioxide + methanol system at 313.15K", Netsu Bussei, vol. 10, pp. 16-20, February 1996.

[5] R. Yaginuma, T. Nakajima, H. Tanaka, and M. Kato, "Volumetric properties and vapor-liquid equilibria for carbon dioxide + 1propanol system at 313.15K", Fluid Phase Equilibria, vol. 144, pp. 203-210, February 1998.

[6] R. Yaginuma, T. Nakajima, H. Tanaka, and M. Kato, "Densities of carbon dioxide + 2-propanol at 313.15K and pressures to 9.8Mpa", J. Chem. Eng. Data, vol. 42, pp. 814-816, July 1997.

[7] D. Kodama, J. Miyazaki, M. Kato, and T. Sako, "High pressure phase equilibrium for ethylene + 1-propanol system at $283.65 \mathrm{~K}$ ", Fluid Phase Equilibria, vol. 219, pp. 19-23, May 2004.

[8] R.L. Smith, Jr., T. Yamaguchi, T. Sato, H. Suzuki, and K. Arai, "Volumetric behavior of ethyl acetate, ethyl octanoate, ethyl laurate, ethyl linoleate, and fish oil ethyl esters in the presence of supercritical $\mathrm{CO}_{2} "$, J. Supercrit. Fluids, vol. 13, pp. 29-36, June 1998. 
[9] R.E. Gibson, and O.H. Loeffler, "Pressure-Volume-Temperature Relations. In Solutions. II. The energy-volume coefficients of aniline, nitrobenzene, bromobenzene and chlorobenzene", J. Am. Chem. Soc., vol. 61, pp. 2515-2522, September 1939.
[10] M. Kato, T. Ono, K. Sugiyama, and D. Kodama, "Correlation of high pressure density behaviors for fluid mixtures made of carbon dioxide with ethyl acetate, 1-propanol, 2-propanol, or methanol at 313.15K", Netsu Bussei, vol. 21, pp. 14-18, February 2007.

(C) Kato et al.; Licensee Bentham Open.

This is an open access article licensed under the terms of the Creative Commons Attribution Non-Commercial License (http://creativecommons.org/licenses/by$\mathrm{nc} / 3.0 /$ ) which permits unrestricted, non-commercial use, distribution and reproduction in any medium, provided the work is properly cited. 